\title{
Socio-Legal Dimensions of Live-In-Relationships in India
}

\author{
Dr. Rabbiraj. C \\ Assistant Professor, Saveetha School of Law, Saveetha University, India
}

\begin{abstract}
Marriage and family is the foundation of Indian culture and tradition. The Indian society is mostly religious and family centric. The influence of live-in-relationships in India is of very recent past which has raised several crucial questions relating to the impact of such relationships on the society. Although, there is no legislation on this subject matter, the Indian judiciary has thrown much light into the issue on live-inrelationships and has prudently tried to balance the general expectations of the society and the individual rights of people. This article highlights the issue of live-in-relationships in India and examines the need to protect the future generation from the influence of live-in-relationships which is no better arrangement than marriage.
\end{abstract}

Key Words: Family, Live-in-relationships, Marriage, Society, Women

\section{Introduction}

India is known for its democracy and family system. Generally people are very much attached to their families and the top most priority of every ideal Indian is his family. The main reason is the kind of faith and respect people have on marriage. The social institution of marriage is the biggest strength of this diversified country. Irrespective of faith, people regard marriage as an integral part of their lives and believe that moral values and traditions are to be followed and preserved for a healthy society. In earlier days, marriages were fixed by parents and elders of the joint family. The modern Indian families are nuclear as most of the people migrate to urban areas for education and livelihood. There is no iota of doubt that the present generation is highly talented and play a vital role in the development of the country. Though the advent of Liberalisation, Privatization and Globalisation has significantly enhanced the economic position of the Indians but has equally weakened the social system of marriage and family in India. The influence has gone to such an extent that people now are getting married late due to higher expectations in relationships and the saddest part is that youngsters these days are not interested in marriage and are gradually shifting towards live-in-relationships. Living together has become more a fashion and non committed way of relationship which has serious implications on the status and rights of women and children as they lack legal and social recognition in the society. India is still looked upon by the world as a country where marriage occupies a sacramental position both philosophically and practically. Thus the object of this paper is to bring out the impact of live-inrelationships in the light of judicial decisions in India.

\section{Religion \& Marriage in India}

Marriages in India take place either following the personal Law of the Religion to which a party is belonged or following the provisions of the Special Marriage Act. Marriage, as per the Common Law, constitutes a contract between a man and a woman, in which the parties undertake to live together and support each other. Marriage, as a concept, is also nationally and internationally recognized. In India marriage is deeply influenced by religion. Hinduism, Christianity and Islam are faiths practised all throughout the country.All these religions have a major role in a person's life and death, especially with the regard to marriage since time immemorial the institution of marriage is greatly woven into the culture and tradition of the people.

\subsection{Hinduism}

Marriage is regarded an important event in the life of a Hindu man because without a wife he cannot enter the Grihastha ashrama ordained by the holy law givers. Besides, without marriage there can be no offspring and without a son, no release from the chain of birth-death-rebirth. The importance of Hindu marriage lies in the fact that, being a religious sacrament is indissoluble. Only death can normally separate those who have been united through holy matrimony.

\subsection{Christianity}

Christian marriage in India is also woven around a lot of religious beliefs and ideas. Marriage, according to Christianity, is one of the sacraments. From the point of view of Christians, marriage is considered very necessary and important. It is not established just for providing sexual satisfaction but for other purposes also. According to Christians, Marriage is a permanent and exclusive contract of love between a man and a 
woman. Marriage is a covenant of love. Love is the basis of marriage. As per the Christian belief, God himself is the author of matrimony, endowed as it is with various benefits and purposes.

\subsection{Islam}

Marriage in Islam is intended to cater to multiple purposes which include, above all, spiritual tranquillity and peace, and cooperation and partnership in fulfilling the divine mandate. Islam aims at rearing a righteous individual, being the cornerstone in the social structure of the nation; it also seeks to establish a sound family, the prime and essential factor in building a good society. In India Muslims consider marriage as bonding that unites a man and a woman in solemn matrimony which is the foundation that gives rise to the family and firmly believe that there is no way a real or proper family could ever exist out of wedlock, the way that has been legislated by god.

\section{Importance of Marriage}

Marriage is important in life because it ensures a psychological satisfaction (that of having a friend for life, family, children) and a biological satisfaction (that of sex) to an individual. It further ensures a twofold survival, that is, of the group and its culture. The economic organization is so much dependent upon cooperation and division of labour between the two sexes, that a stable functioning is possible only when the two sexes enter into socially sanctioned and permanent or semi- permanent relations with each other, i.e., marriage. Thus the marital bond among the people of India is found to bring together not just two individuals, but two families even kindred and villages. It is not a tool meant to secure for individuals satisfaction of a highly personal character, but a social mechanism designed to create and foster social solidarity.

Entering into marriage therefore is to enter into a relationship that has public significance as well. The institutions of marriage and the family are important social institutions that provide for the security, support and companionship of members of our society and bear an important role in the rearing of children. The celebration of a marriage gives rise to moral and legal obligations, particularly the reciprocal duty of support placed upon spouses and their joint responsibility for supporting and raising children born of the marriage. These legal obligations perform an important social function. Marriage as an institution has great legal significance and various obligations and duties flow out of marital relationship, as per law, in the matter of inheritance of property, succession ship, etc. Marriage, therefore, involves legal requirements of formality, publicity, exclusivity and all the legal consequences flow out of that relationship. In contemporary urban society marriage has become highly individualistic and personal.

\section{The concept of Live-in-relationships}

Live-in-relationships are very common in many western countries. The understanding of live-inrelationship is that it is an arrangement of living under which the couples who are unmarried live together to conduct a long going relationship similarly as in marriage. The main idea, of a live-in-relationship is that the interested couple wanted to test their compatibility for each other before going for some commitment. Live-inrelationship is a de facto union in which couple shares common bed-room without solemnizing marriage. It is non-marital relationship prevailing in West with the different name like, common law marriages, informal marriages or marriage by habit, deemed marriages etc. It is a form of interpersonal status which is legally recognized in some jurisdictions as a marriage even though no legally recognized marriage ceremony is performed or civil marriage contract is entered into or the marriage registered in a civil registry. Live-inrelationships are practiced mostly in the metropolitan cities. Such practice is still a social taboo in a major part of India which is constituted by villages and towns. There is a gradual transition from the sacrament of arranged marriages to love marriages and ultimately to live-in relationships, due to many reasons like lack of tolerance and commitment.

\section{Law \& Judiciary on the status on Live-in-Relationships}

In India, till date there is no specific legislation to deal on the subject matter on live-in relationship and the Protection of Women from Domestic Violence Act, 2005 provides some kind of protection to the aggrieved parties from any kind of atrocities faced by the females living in relationship in the nature of marriage. This Act has been widely hailed as the first legal Act to recognize the existence of non-marital adult heterosexual relations. This Act defines an aggrieved person who will be covered under this Act as "any woman who is, or has been, in a domestic relationship with the respondent and who alleges to have been subjected to any act of domestic violence by the respondent."

The Act further defines a domestic relationship as "a relationship between two persons who live or have, at any point of time, lived together in a shared household, when they are related by consanguinity, marriage, or through a relationship in the nature of marriage, adoption or are family members living together as a joint family." The main intention of this provision is to protection the interest of women from all kinds of 
domestic violence irrespective of the status and recognises the domestic relationships between men and women without conferring any special legal status to the parties. In other words it merely seeks to denounce domestic violence in any quarter. The existing laws are not effective enough to protect the rights of live-in-relationship partners. Justice Mallimath Committee as well as the Law Commission of India states that if a woman has been in a live-in-relationship for a reasonable period, she should enjoy the legal rights of the wife. The Committee also recommended the amendment of the definition of wife under Section 125 of the Criminal Procedure Code (Cr.P.C) so that a woman in live-in-relationship can get the status of a wife. Still consensus has not been reached over the recommendations of the committee.

\subsection{Indian Judiciary on Live-in-Relationships}

As far as Indian judiciary is concerned, the understanding of marriage and the notion of live-inrelationship has gradually moved from the traditional view to the modern life of the changing society. Live-inrelationship is gaining momentum especially amongst the educated and economically viable groups conscious about their rights. There are serious concerns about such changing trends in the society i.e., the rights and obligation which such couples have towards each other and the status of children born out of such a tie exudes a blurred shadow. No law on the subject has been formulated. The law is adumbrated in the court rooms via myriad cases. When it comes to live-in-relationships, in the recent past the court tended to presume marriage based on the number of years of cohabitation.

Before independence in A.Dinohamy v.WL Blahamy, the Privy Council laid down a broad rule postulating that, "Where a man and a woman are proved to have lived together as a man and wife, the law will presume, unless the contrary be clearly proved, that they were living together in consequence of a valid marriage and not in a state of concubinage." The same principle was reiterated in the case of Mohabhat Ali v. Mohammad Ibrahim Khan. After independence the first case that can be reviewed is Badri Prasad v. Dy. Director of Consolidation, wherein the Supreme Court recognised live-in-relationships as valid marriage, putting a stop to questions raised by authorities on the 50 years of life in relationship of a couple.

The position now is far changing and commendable. There is a paradigm shift now in the understanding of live-in-relationship by the courts from earlier cases and have postulated that live in relationship are not illegal per se. The Allahabad High Court, in Payal Sharma v. Superintendent, Nari Niketan, and others, stated that a live-in-relationship is not illegal. Justice M Katju and Justice R.B. Mishra stated, "In our opinion, a man and a woman, even without getting married, can live together if they wish to. This may be regarded as immoral by society, but is not illegal. There is a difference between law and morality." In Patel and others case, the Supreme Court observed that live- in-relationship between two adults without a formal marriage cannot be construed as an offence. It also stated that there is no such statute which postulates that live-in relationships are illegal. The same proposition was upheld in the case of Tulsa v. Durghatiya, where the long term live-in-relationship was recognised as equivalent to marriage.

In Kushboo vs Kanniammal the opinion of the Supreme Court has further provided a positive impetus to live-in- relationships. The case of the prosecution was that the comment of the actress Khushboo allegedly endorsing pre-marital sex will adversely affect the moral fabric of society. A three judge bench comprising of Chief Justice K.G. Balakrishnan, Justice Deepak Verma and Justice B.S. Chauhan observed, "When two adult people want to live together what is the offence. Does it amount to an offence? Living together is not an offence. It cannot be an offence". The court further said "Please tell us what is the offence and under which section. Living together is a right to life", thereby referring to the right to life guaranteed under Article 21. However, this position is not all binding. The Delhi High Court, in another case, observed that a live in relationship is a walk in and walk out relationship. Justice S.N. Dhingra noted, "There are no legal strings attached to this relationship nor does this relationship create any legal-bond between the partners". The court further added, "People who choose to have live-in-relationship cannot complain of infidelity or immorality as live-in-relationships are also known to have been between a married man and unmarried woman or vice-versa" The Indian courts have time again tried to intercede in matters relating to live-in-relationship and opened the gates of hope for the people. Adding feather to the cap, the Supreme Court of India in D.Velusamy v D.Patchaiammal differentiated between "live-in relationship" and "relationship in the nature of marriage" and laid conditions for women seeking maintenance in live-in-relationship. In the judgement Justices Markandey Katju and T S Thakur opined that in order to get maintenance, a woman, even if not married, has to fulfill the following four requirements: accordingly maintenance claim can me sought by the spouse.(1)The couple must hold themselves out to society as being akin to spouses (2)They must be of legal age to marry (3)They must be otherwise qualified to enter into a legal marriage including being unmarried (4)They must have voluntarily cohabitated and held themselves out to the world as being akin to spouses for a significant period of time. The court further stated that a "relationship in the nature of marriage" under the Domestic Violence Act 2005 must also fulfil the above requirements, and in additions the parties must have lived together in a "shared household" as defined in Section 2(S) of the Act. Merely spending weekends together or a one night stand would not make 
it domestic relationship. Justice Katju further elaborated, "In our opinion not all live-in relationships will amount to a relationship in the nature of marriage to get the benefit of the Act of 2005. To get such benefit the conditions mentioned by us above must be satisfied, and this has to be proved by evidence. If a man has a 'keep' whom he maintains financially and uses mainly for sexual purpose and or as a servant, it would not, in our opinion, be a relationship in the nature of marriage. No doubt the view we are taking would exclude many women who have had a live-in relationship from the benefit of the 2005 Act, but then it is not for this court to legislate or amend the law."

Similarly the other major concern was deciding the legitimacy of the children born out of live-inrelationship, once again the Supreme Court highlighted the plight of children born out of live-in-relationship in the case of Uday Kumar v Ayesha \& others the bench of Justices B S Chauhan and Justice Chelameswar stated that children born out of prolonged live-in relationships could not be termed illegitimate. This judgement has overshadowed all the earlier understanding regarding the legitimacy of the children born out of live-inrelationships. Hence, though more or less uniformity has been exuded in a positive direction by the court when it comes to live-in-relationship. These developments have definitely changed the position and understanding of live-in-relationships but these developments are not enough to face the future challenges. The above decisions of the court may pave way for many more people to engage in this kind of relationships. This kind of arrangement of living together is slowly getting approval and acceptance among the educated masses which strongly believe that such arrangements of living together will break all social and moral sentiments relating to marriage such dowry, caste, religion, language, region, nationality, profession etc and will create a tolerant and rational society. Though the intentions are noble and praiseworthy behind such arrangements of living together but in practicality it is more a disaster than a relief as the experiences from the west clearly manifest that no arrangements are as worthy and binding as that of marriage.

\section{Conclusion}

In a country like India, respect for human rights is an integral part of democratic system. Every individual has the freedom to choose his life and life partner for setting up a family through marriage. The purpose of marriage is to create a sense of commitment irrespective of its pitfalls. Marriage is no guarantee for everlasting happiness but provides legal and social recognition and protection in the society. The changing scenario of people moving into live-in-relationships is an issue of individual right and privacy. Though the number of people supporting such practice may be less in number but there is a genuine concern that in future people may prefer it for marriage. In the absence of legislation, judiciary in India through its wisdom has immensely contributed in understanding the problems relating to live-in-relationships and has maintained a balanced position. The idea of live-in-relationships may seem to be very unique and appealing but in reality the problems likely to arise are many and challenging. Encouraging live-in-relationships in the existing circumstances will invite problems like bigamy, multiple partner relationships which will destroy the social fabric of this country. The status of the women in such relationship is not that of a wife and lacks social approval or sanctity. The chances of exploitation of women in such relationships will be in rise due to the absence law. One of the studies reveal that the chances of couples begetting children are very less as couples usually prefer not to have children. On the other hand couples having children and not continuing the relationship will adversely affect the interest of the children due to lack of love and parental care. Increase in litigation on matters pertaining to maintenance, legitimacy of children, inheritance etc is another area of great concern. It is true that society needs to change according to changing times but at the same time it should not compromise with the moral values and traditions of the society in the name of modernisation. Hence, the need of the hour is to educate and enlighten the present generation about the real importance of marriage and family. This can be possible only when the parents respect the feelings and aspirations of their children and give them the freedom of choice in their marriage.

\section{References}

[1]. Indra Sarma v. V.K.V. Sarma [Criminal Appeal No. 2009 of 2013 @ Special Leave Petition (CRL.) No.4895 of 2012]

[2]. O'Regan, J., in Dawood and Another v. Minister of Home Affairs and Others 2000 (3) SA 936 (CC)

[3]. A Dinohamy v. WL Blahamy (1928) 1 MLJ 388 (PC)

[4]. Mohabhat Ali v. Mohammad Ibrahim Khan AIR 1929 PC 135

[5]. Badri Prasad v. Dy. Director of Consolidation AIR 1978 SC 1557

[6]. Payal Sharma v. Superintendent, Nari Niketan, and others 2001 (3) AWC 1778

[7]. In Patel and others case (2006) 8 SCC 726

[8]. Tulsa v. Durghatiya (2008) 4 SCC 520

[9]. Kushboo v.Kanniammal JT 2010 (4) SC 478

[10]. Alok Kumar v. State Crl.M.C.No. 299/2009

[11]. D. Velusamy v. D. Patchaiammal, (2010) 10 SCC 469

[12]. Uday Gupta v. Aysha \& Anr. SPECIAL LEAVE PETITION (Crl.) No. 3390 OF 2014 (Crl M.P. No.6817 of 2014)

[13]. Bharatha Matha \& Anr. v. R.Vijaya Renganathan \& Ors. 2010 STPL (Web) 406 SC.

[14]. http://www.importantindia.com/3886/why-marriage-is-important-in-life/VivekMurarka, (accessed on 12.6.2014) 
[15]. http://timesofindia.indiatimes.com/india/SC-lays-down-conditions-for-women-seekingmaintenance-in-live-inrelationships/opinions/6786239.cms (accessed on 2.6.2014)

[16]. http://forum.santabanta.com/showthread.htm?313507-Supreme-Court-of-India-clarifies-live-in-relationship-!(accessed on 2.6.2014)

[17]. See more at: http://www.lawweb.in/2014/05/sc-judgment-on-legality-of-live-in.html\#sthash.9pTO5SsZ.dp (accessed on 9.6.2014)

[18]. http://liveinrelationshipinindia15.blogspot.in/2012/09/live-in-relationship-legality.html (accessed on 7.6.2014)

[19]. http://timesofindia.indiatimes.com/india/SC-lays-down-conditions-for-women-seekingmaintenance-in-live-inrelationships/opinions/6786239.cms (accessed on 3.6.2014)

[20]. http://www.indialawjournal.com/volume2/issue_2/article_by_saakshi.html, (accessed on 2.07.2014)

[21]. Love 'live-ins' - Man-Woman - Relationships - Life \& Style - The Times of India http:/timesofindia.indiatimes.com/lifestyle/relationships/man-woman/Love-live-ins/articleshow/6386392.cms\#ixzz0xKIknHki (accessed on 3.07.2014)

[22]. Rights specific to female live in partner such as right under Domestic Violence Act, 2005

[23]. http://airwebworld.com/articles/index.php?article=1266 (accessed on 2.07.2014)

[24]. http://projectcloud.info/research-paper-idea/live-in-relationship-review-and-analysis-srishti-aishwarya/\#sthash.Bj45uyZU.dpbs (accessed on 4.7.2014)

[25]. http://www.marriage.co.in/changing-trends-in-indian-marriage.html (accessed on 2.6.2014) 